\title{
Evaluation of Maize (Zea mays L.) Varieties for Moisture Stress Areas in Humbo District, Wolaita Zone, Southern Ethiopia
}

\author{
Gobeze Loha ${ }^{1}$, Abebe Endale ${ }^{2}$, Rahel Tigabu ${ }^{3}$, Abdishikur Reshid ${ }^{2}$, \\ Zemach Sorsa ${ }^{4}$ and Senapathy, M. ${ }^{5^{*}}$
}

\begin{abstract}
${ }^{1}$ Department of Plant Sciences, College of Agriculture, Wolaita Sodo University, Ethiopia, East Africa ${ }^{2}$ Department of Plant Science, College of Agriculture, Wolaita Sodo University, Ethiopia, East Africa ${ }^{3}$ Department of Plant Science, College of Agriculture, Medawolabu University, Goba, Ethiopia, East Africa ${ }^{4}$ Department of Plant Science, College of Agriculture, Wolaita Sodo University, Ethiopia, East Africa ${ }^{5}$ Department of Rural Development and Agricultural Extension, College of Agriculture, Wolaita Sodo University, Ethiopia, East Africa
\end{abstract}

*Corresponding author: mspathy9@gmail.com (ORCID ID: 0000-0002-8371-3035)

Paper No. 883

Received: $11-12-2020$

Revised: 14-01-2021

Accepted: 28-02-2021

\begin{abstract}
Maize is a priority crop to farmers because it is a staple food in many rural communities of the southern region. It is widely grown in the various parts of the southern region, from lowland to mid-highlands. On the other hand, moisture stress is one of the most critical production constraints of maize in low to intermediate agroecology. Thus, developing maize varieties tolerant to moisture is of paramount importance to sustain maize production in moisture areas. In this context, field experiments were conducted during 201617 croppings at Kindo Koyisha and Humbo to select adaptable maize varieties for moisture stress areas with reasonable grain yield. Treatments used in this study were eight maize varieties (BH546, BH547, Gibe II, MH130, Melkasa IV, MH140, Melkasa II, and Melkasa 6Q) and three local cultivars (Local red, Local mixed, and Local white) of the total of eleven maize genotypes were evaluated at two moisture-prone areas in southern Ethiopia. Treatments were laid out in a randomized complete block design (RCBD) with three replications. Maize varieties exhibited different performances at two tested locations. The varieties had the relatively superior performance of Kindo Koyisha as compared to Humbo. The Humbo varieties MH140, MH130, BH546, and Melkasa IV, have yielded relatively higher grain than the rest of the areas. At the same time, the Kindo Koyisha maize varieties expressed relatively better performance concerning grain yield. It has been recorded that the varieties with superior performance with sounding grain yield were BH546, MH140, BH547, and MH130 in these locations. Based on this result, BH546, MH140, and MH130 could be used at both locations. Moreover, BH547 at Bale and Melkasa IV at Humbo also be used in respective locations for production.

\section{Highlights}

(- Complete set of genes inherited by an individual important for expressing a trait under consideration in a particular environment.

( All maize varieties emerged as superior performer at Kindo Koyisha than that of Humbo.

( $\mathrm{BH} 546, \mathrm{MH140}$, and MH130 could be used at both locations for achieving potential sustainable yield.
\end{abstract}

Keywords: Maize varieties and moisture stress

Maize (Zea mays L.) has become the third most important cereal crop in the world because of its high adaptability and productivity (Mosisa et al. 2002). Globally, maize is cultivated under diverse climatic conditions but yields best under moderate
How to cite this article: Loha, G., Endale, A., Tigabu, R., Reshid, A., Sorsa, Z. and Senapathy, M. 2021. Evaluation of Maize (Zea mays L.) Varieties for Moisture Stress Areas in Humbo District, Wolaita Zone, Southern Ethiopia. IJAEB, 14(1): 75-82.

Source of Support: None; Conflict of Interest: None 
temperatures with sufficient water (Parewa et al. 2010). The African continent is the essential food crop and mainstay of rural diets in the eastern and southern regions (FAO, 2003; Maredia et al. 2000; Pingali and Pandey, 2001). Maize has a higher carbohydrate production potential per unit of land than other cereals and was the first major cereal to undergo a rapid and widespread technological transformation in its cultivation (Palwal, 2000). In developed countries, maize is grown mainly for animal feed and raw materials for industrial products, such as starch, glucose, dextrose, and biofuel. Therefore, maize occupies an important position in Africa and the global economy, where it is traded as food, feed, and industrial grain crop (Vasal 2000).

In Ethiopia, cereals account for about $82.34 \%$ of the annual national crop production. Maize ranks first in total production and yield per unit area and second in area coverage among all the cereals. It is largely produced in western, central, southern, and eastern regions (CSA, 2010). Maize research has advanced from landraces to maize hybrids: double cross, three-way cross, single cross, and recently transgenic maize hybrids. The optimized use of adapted and exotic germplasm in various production environments is a key to the continued success in increasing grain yield and other traitspecific products: green ear, forage, oil, protein, starch.

Moreover, maize is a priority crop to farmers because it is a staple food in many rural communities of the southern region. It is widely grown in the various parts of the southern region, from lowland to midhighlands. On the other hand, moisture stress is one of the most critical production constraints of maize in low to intermediate agroecology. However, the extent of yield reduction due to moisture stress varies with genotypes. Developing maize varieties tolerant to moisture is of paramount importance to sustain maize production in moisture areas. Hence, the objective of this study was to select adaptable maize varieties for moisture stress with reasonable grain yield.

\section{MATERIALS AND METHODS}

\section{Experimental site}

Field experiments were conducted during 2016/17 cropping at Kindo Koyisha (Altitude 1170 masl, annual rainfall $924 \mathrm{~mm}, 2100$, significant crops cultivated in the study area include maize, sorghum, and sweet potato) and Humbo (Altitude 1800, annual rainfall 1295 with bimodal rainfall patterns, average temperature of $20^{\circ} \mathrm{C}$ ).

\section{Treatments and experimental design}

Treatments used in this study were eight maize varieties (BH546, BH547, Gibe II, MH130, Melkasa IV, MH140, Melkasa II, and Melkasa 6Q) and three local cultivars (Local red, Local mixed, and Local white) of the total of eleven maize genotypes were evaluated at two moisture-prone areas in southern Ethiopia. The Treatments were laid out in a Randomized Complete Block Design (RCBD) with three replications. The plot size was $4 \times 4 \mathrm{~m}$ with $1.5 \mathrm{~m}$ between replications and $1.0 \mathrm{~m}$ between plots. Planting was carried out as per the planting time of the respective area following the onset of rainfall. Maize was hand planted by placing two seeds per hill and thinned after emergence to maintain the proposed plant density per plot. Weed control was carried out by hand or hand hoeing, while diseases and insect damage were visually monitored during crop growing season. Phosphorus fertilizer in the form of DAP and $\mathrm{N}$ in the form of urea was applied as per recommendation for maize production. Moreover, other crop management practices carried out as desired.

\section{Data collection and measurements}

Data recorded on yield components included ear length, ear diameter, number of seeds per row, kernels per ear, thousand seed weight, and prolificacy (ears per plant). Ear length and diameter were measured for five randomly selected plants from the base to the tip and approximately the middle of the ear at harvesting. The number of seeds per row was counted for five randomly selected plants. Seed number per ear was determined by multiplying the number of rows by the number of seeds per row. Thousand Seed Weight (TSW) was measured by counting a thousand seeds with a seed counter and weighing it with sensitive balance. Prolificacy is the property of producing more ears per plant and is estimated by dividing the number of ears by the number of plants per plot. Grain was manually harvested from the net plot and converted to $\mathrm{kg} / \mathrm{ha}$ after adjusting the moisture content to 
$12.5 \%$. Biomass yield was estimated as the sum of stover weighed and grain yield. Harvest Index (HI) is the ratio of grain yield to the total biomass yield, which was estimated by dividing grain yield by total biomass. Data were subjected to analysis of variance using the general linear model SAS version 9.1 (SAS Inst., 2003). Treatments means were compared using the least significant difference (LSD) at a 5\% probability level.

\section{RESULTS AND DISCUSSION}

\section{Plant and ear heights}

The data for plant and ear heights as affected by location and varieties are depicted in Table 1.

Table 1: Plant and ear heights as affected by location and varieties

\begin{tabular}{|c|c|c|c|}
\hline Location & Variety & Plant height & Ear height \\
\hline \multirow{11}{*}{ Kindo Koyisha } & BH546 & 291 & $124 \mathrm{bc}$ \\
\hline & BH547 & 268 & $147 a$ \\
\hline & Gibe II & 228 & 103de \\
\hline & MH130 & 204 & $82 \mathrm{fg}$ \\
\hline & Melkasa IV & 201 & $88 \mathrm{ef}$ \\
\hline & MH140 & 259 & $121 \mathrm{~cd}$ \\
\hline & Melkasa II & 217 & $88 \mathrm{ef}$ \\
\hline & Melkasa 6Q & 202 & $82 \mathrm{fg}$ \\
\hline & Local red & 244 & $141 \mathrm{ab}$ \\
\hline & Local mixed & 245 & $144 a$ \\
\hline & Local white & 255 & $148 \mathrm{a}$ \\
\hline \multirow{12}{*}{ Humbo } & BH546 & 178 & $72 \mathrm{f}-\mathrm{g}$ \\
\hline & BH547 & 189 & $86 \mathrm{ef}$ \\
\hline & Gibe II & 155 & 57hi \\
\hline & MH130 & 117 & $40 \mathrm{ij}$ \\
\hline & Melkasa IV & 135 & 54hi \\
\hline & MH140 & 150 & 58hi \\
\hline & Melkasa II & 136 & 54hi \\
\hline & Melkasa 6Q & 110 & $34 j$ \\
\hline & Local red & 148 & 57hi \\
\hline & Local mixed & 153 & $65 \mathrm{gh}$ \\
\hline & Local white & 122 & 55hi \\
\hline & LSD & NS & 18 \\
\hline \multirow{12}{*}{ Variety mean } & BH546 & $235 a$ & $98 b c$ \\
\hline & BH547 & $229 a$ & $117 \mathrm{a}$ \\
\hline & Gibe II & $191 b c$ & 80de \\
\hline & MH130 & 161ef & $61 \mathrm{f}$ \\
\hline & Melkasa IV & 168d-f & $71 \mathrm{ef}$ \\
\hline & MH140 & $205 b$ & $90 \mathrm{~cd}$ \\
\hline & Melkasa II & 177c-e & 71ef \\
\hline & Melkasa 6Q & $156 f$ & $58 f$ \\
\hline & Local red & $196 b c$ & $99 b c$ \\
\hline & Local mixed & $199 b$ & $105 \mathrm{ab}$ \\
\hline & Local white & $188 b-d$ & $101 b c$ \\
\hline & LSD & 21 & 13 \\
\hline
\end{tabular}

\begin{tabular}{|c|c|c|c|}
\hline \multirow{4}{*}{ Location mean } & Kindo Koyisha & $238 a$ & $115 a$ \\
\hline & Humbo & $145 b$ & $58 b$ \\
\hline & LSD & 9 & 5 \\
\hline & CV $(\%)$ & 9.2 & 13.3 \\
\hline
\end{tabular}

Means followed by the same letters within a column are not significantly different at 5\% probability level, NS = not significant.

Analysis o variance indicated that location had a significant effect on plant and ear height. Both parameters were higher at Kindo Koyisha as compared to Humbo. Similarly, maize varieties have significantly differed for plant height and ear height. The tallest plant height $(235 \mathrm{~cm})$ was recorded for variety $\mathrm{BH} 547$, followed by variety $\mathrm{BH} 547$ with a mean plant height of $229 \mathrm{~cm}$. The shortest plant height $(156 \mathrm{~cm})$ was seen for variety Melkasa 6Q. In line with this, the tallest ear heights $(117 \mathrm{~cm})$ were observed for BH547, followed by a variety of Local mixed with a mean ear height of $58 \mathrm{~cm}$.

On the other hand, location by variety interactions resulted in significant differences in on-ear heights (Table 1). Generally, all varieties exhibited taller ear heights at Kindo Koyisha as compared to Humbo. The tallest ear height $(148 \mathrm{~cm})$ was observed for variety Local white at Humbo, followed by variety BH547 at Kindo Koyisha with a mean ear height of $147 \mathrm{~cm}$. The shortest ear height $(34 \mathrm{~cm})$ was seen for variety Melkasa 6Q at Humbo. In contrast, location by varieties interaction did not have a significant effect on plant heights.

\section{Ear length and ear diameter}

The data for ear length and ear diameter as affected by location and varieties are presented in Table 2 . Analysis of variance showed that the main effect of location and varieties had significant differences in length. The ear length of maize varieties was higher at Kindo Koyisha than that of Humbo. Averaged over locations, the longest cob length $(15.13 \mathrm{~cm})$ was obtained from variety BH546, followed by variety BH547 with a mean ear length of $13.74 \mathrm{~cm}$. The shortest ear diameter $(11.62 \mathrm{~cm})$ was seen for variety Melkasa 6Q. In line with this, the interaction of location by varieties resulted in significant differences in ear length (Table 2). The most extended ear length $(15.83 \mathrm{~cm})$ was recorded for variety BH546 at Kindo Koyisha, followed by variety BH547 with a mean cob length of $14.45 \mathrm{~cm}$ at the exact location. The shortest ear length (9.69 $\mathrm{cm}$ ) was seen for local white at Humbo. 
?

On the other hand, the only main effect of varieties exhibited significant differences in ear length. The longest cob diameter $(4.75 \mathrm{~cm})$ was measured for variety $\mathrm{BH} 546$, followed by variety $\mathrm{BH} 547$ with a mean ear diameter of $4.34 \mathrm{~cm}$. The shortest ear diameter $(4.03 \mathrm{~cm})$ was observed for local white. However, the main effect of location and its interactions with varieties did not significantly affect ear diameter.

Table 2: Cob length and diameter as affected by location and varieties

\begin{tabular}{|c|c|c|c|}
\hline Location & Variety & $\begin{array}{l}\text { Cob length } \\
(\mathrm{cm})\end{array}$ & $\begin{array}{l}\text { Cob diameter } \\
(\mathrm{cm})\end{array}$ \\
\hline \multirow{11}{*}{$\begin{array}{l}\text { Kindo } \\
\text { Koyisha }\end{array}$} & BH546 & $15.83 a$ & 4.37 \\
\hline & BH547 & $14.45 a-c$ & 4.79 \\
\hline & Gibe II & $12.71 c-f$ & 4.19 \\
\hline & MH130 & $13.09 \mathrm{c}-\mathrm{f}$ & 4.31 \\
\hline & Melkasa IV & $14.15 a-d$ & 4.26 \\
\hline & MH140 & $13.64 b-e$ & 4.39 \\
\hline & Melkasa II & 12.91c-f & 4.03 \\
\hline & Melkasa 6Q & 11.97ef & 4.34 \\
\hline & Local red & $12.29 \mathrm{~d}-\mathrm{f}$ & 4.27 \\
\hline & Local mixed & $12.96 \mathrm{c}-\mathrm{f}$ & 4.45 \\
\hline & Local white & 12.10ef & 4.17 \\
\hline \multirow{12}{*}{ Humbo } & BH546 & $14.43 a-c$ & 4.32 \\
\hline & BH547 & $13.03 \mathrm{c}-\mathrm{f}$ & 4.71 \\
\hline & Gibe II & $12.69 c-f$ & 4.33 \\
\hline & MH130 & $11.96 \mathrm{ef}$ & 3.95 \\
\hline & Melkasa IV & $12.24 \mathrm{ef}$ & 3.99 \\
\hline & MH140 & $12.77 c-f$ & 4.16 \\
\hline & Melkasa II & 11.89ef & 4.13 \\
\hline & Melkasa 6Q & $11.27 \mathrm{fg}$ & 4.19 \\
\hline & Local red & $12.66 \mathrm{c}-\mathrm{f}$ & 4.25 \\
\hline & Local mixed & $12.62 \mathrm{c}-\mathrm{f}$ & 4.25 \\
\hline & Local white & $9.69 \mathrm{~g}$ & 3.89 \\
\hline & LSD & 1.90 & NS \\
\hline \multirow{12}{*}{$\begin{array}{l}\text { Variety } \\
\text { mean }\end{array}$} & BH546 & $15.13 a$ & $4.75 \mathrm{a}$ \\
\hline & BH547 & $13.74 b$ & $4.34 \mathrm{~b}$ \\
\hline & Gibe II & $12.70 b c$ & $4.26 b c$ \\
\hline & MH130 & $12.53 b c$ & $4.13 b c$ \\
\hline & Melkasa IV & $13.19 b$ & $4.13 b c$ \\
\hline & MH140 & $13.20 \mathrm{~b}$ & $4.27 \mathrm{bc}$ \\
\hline & Melkasa II & $12.40 \mathrm{bc}$ & $4.08 \mathrm{c}$ \\
\hline & Melkasa 6Q & $11.62 \mathrm{c}$ & $4.27 \mathrm{bc}$ \\
\hline & Local red & $12.48 b c$ & $4.26 \mathrm{bc}$ \\
\hline & Local mixed & $12.79 b c$ & $4.35 b$ \\
\hline & Local white & $12.39 b c$ & $4.03 c$ \\
\hline & LSD & 1.34 & 0.24 \\
\hline
\end{tabular}

\begin{tabular}{|c|c|c|c|}
\hline \multirow{4}{*}{$\begin{array}{l}\text { Location } \\
\text { mean }\end{array}$} & \multicolumn{2}{|c|}{ Kindo Koyisha $13.55 a$} & 4.32 \\
\hline & Humbo & $12.29 b$ & 4.19 \\
\hline & LSD & 0.57 & NS \\
\hline & CV (\%) & 8.9 & 4.9 \\
\hline
\end{tabular}

Means followed by the same letters within a column are not significantly different at 5\% probability level, NS = not significant

Rows per ear, seeds per row, seeds per ear, and thousand seed weight

The number of rows per ear seeds per row, seeds per ear, and TSW as affected by location and varieties are shown in Table 3.

Table 3: Number of rows per cob, seeds per row, seeds per cob and TSW as affected by location and varieties

\begin{tabular}{|c|c|c|c|c|c|}
\hline Location & Variety & $\begin{array}{l}\text { Rows } \\
\text { per ear }\end{array}$ & $\begin{array}{l}\text { Seeds } \\
\text { per row }\end{array}$ & $\begin{array}{l}\text { Seeds } \\
\text { per ear }\end{array}$ & $\begin{array}{l}\text { TSW } \\
\text { (g) }\end{array}$ \\
\hline \multirow{11}{*}{$\begin{array}{l}\text { Kindo } \\
\text { Koyisha }\end{array}$} & BH546 & 13.6 & $36 a$ & 531 & 295 \\
\hline & BH547 & 14.8 & $34 \mathrm{ab}$ & 481 & 329 \\
\hline & Gibe II & 13.2 & $29 c-g$ & 387 & 281 \\
\hline & MH130 & 13.6 & $33 a-c$ & 402 & 311 \\
\hline & Melkasa IV & 13.6 & 31b-e & 408 & 296 \\
\hline & MH140 & 14.8 & $30 b-f$ & 441 & 322 \\
\hline & Melkasa II & 13.3 & $30 b-e$ & 407 & 285 \\
\hline & Melkasa 6Q & 15.3 & $27 d-h$ & 444 & 278 \\
\hline & Local red & 13.8 & $26 \mathrm{e}-\mathrm{h}$ & 357 & 341 \\
\hline & Local mixed & 13.2 & $27 d-h$ & 373 & 356 \\
\hline & Local white & 12.8 & $29 c-f$ & 327 & 369 \\
\hline \multirow{12}{*}{ Humbo } & BH546 & 13.0 & $31 b-d$ & 407 & 376 \\
\hline & BH547 & 15.3 & $27 \mathrm{e}-\mathrm{h}$ & 410 & 347 \\
\hline & Gibe II & 14.3 & $27 e-h$ & 382 & 320 \\
\hline & MH130 & 13.0 & 24hi & 314 & 309 \\
\hline & Melkasa IV & 13.0 & $26 f-i$ & 334 & 344 \\
\hline & MH140 & 14.3 & $24 g-i$ & 348 & 368 \\
\hline & Melkasa II & 14.3 & 24hi & 339 & 315 \\
\hline & Melkasa 6Q & 14.3 & $26 f-i$ & 369 & 285 \\
\hline & Local red & 13.0 & $29 c-f$ & 374 & 315 \\
\hline & Local mixed & 12.7 & $28 \mathrm{~d}-\mathrm{g}$ & 360 & 338 \\
\hline & Local white & 12.0 & $22 \mathrm{i}$ & 262 & 332 \\
\hline & LSD & NS & 4 & NS & NS \\
\hline \multirow{12}{*}{$\begin{array}{l}\text { Variety } \\
\text { mean }\end{array}$} & BH546 & $13.3 c-e$ & $34 a$ & $469 a$ & $336 a-c$ \\
\hline & BH547 & $15.1 \mathrm{a}$ & $30 b$ & $445 \mathrm{ab}$ & $338 a b$ \\
\hline & Gibe II & 13.8a-e & $28 b c$ & $384 c$ & $301 \mathrm{~cd}$ \\
\hline & MH130 & $13.3 c-e$ & $28 b c$ & $358 \mathrm{c}$ & $310 b-d$ \\
\hline & Melkasa IV & $13.3 c-e$ & $28 b c$ & 371c & $320 a-c$ \\
\hline & MH140 & $14.6 \mathrm{a}-\mathrm{c}$ & $27 \mathrm{bc}$ & $394 b c$ & $345 \mathrm{ab}$ \\
\hline & Melkasa II & $13.8 \mathrm{a}-\mathrm{d}$ & $27 \mathrm{bc}$ & $373 c$ & $299 \mathrm{~cd}$ \\
\hline & Melkasa 6Q & $14.8 \mathrm{ab}$ & $27 \mathrm{bc}$ & $406 b c$ & $282 d$ \\
\hline & Local red & 13.4b-e & $28 b c$ & $366 c$ & $328 a-c$ \\
\hline & Local mixed & $12.9 \mathrm{de}$ & $28 b c$ & $367 c$ & $347 a$ \\
\hline & Local white & $12.4 \mathrm{e}$ & $26 c$ & $295 d$ & $351 a$ \\
\hline & LSD & 1.4 & 3 & 53 & 36 \\
\hline
\end{tabular}




\begin{tabular}{|c|c|c|c|c|c|}
\hline \multirow{5}{*}{$\begin{array}{l}\text { Location } \\
\text { mean }\end{array}$} & Kindo & 13.8 & $30 a$ & $414 a$ & 314 \\
\hline & Koyisha & & & & \\
\hline & Humbo & 13.6 & $26 b$ & $355 b$ & 332 \\
\hline & LSD & NS & 1 & 22 & NS \\
\hline & CV (\%) & 8.8 & 9.2 & 12.0 & 9.7 \\
\hline
\end{tabular}

Means followed by the same letters within a column are not significantly different at 5\% probability level, NS = not significant.

Analysis of variance indicated that the main effect of location had a significant effect on the number of seeds per row and seeds per ear. Both parameters were higher at Kindo Koyisha as compared to that of Humbo. Similarly, varieties exhibited significant differences in rows per ear, seeds per row, seeds per ear, and TSW (Table 3). Variety BH547 produced the highest number per ear (15.1), followed by variety Melkasa 6Q with a mean number of rows per ear of 14.8. The least number of rows per cob (12.4) was seen for Local white. In line with this, the most significant number of seeds per row (34) and seeds per cob (469) were recorded for variety BH546, followed by variety $\mathrm{BH} 547$ with the mean number of seeds per row and seeds per ear of 30 and 445, respectively. Local white yielded the lowest number of seeds per row (26) and seeds per ear (295).

Moreover, location by variety interactions resulted in a significant number of seeds per row. The greatest number of seeds per row (36) was recorded that Kindo Koyisha for variety BH546, followed by the exact location for variety BH547 with the mean number of seeds per row of 34 . The lowest number of seeds per row (22) was seen for Local white. In contrast, the main effect of location, variety, and interactions did not significantly affect TSW, seeds per row, and rows per ear (Table 3).

\section{Biomass, grain yield and harvest index}

The data for biomass, grain yield, and HI as affected by location and variety are depicted in Table 4 . The location did not have a significant effect on the biomass yield of maize varieties. However, varieties exhibited significant differences in biomass yield. Biomass yield for maize varieties ranged from 7083 to $14792 \mathrm{~kg} / \mathrm{ha}$, with the highest biomass yield recorded $(14792 \mathrm{~kg} / \mathrm{ha})$ for variety $\mathrm{BH} 546$, followed by variety BH547 biomass yield of 14688 $\mathrm{kg} / \mathrm{ha}$. The lowest biomass yield (7083 kg/ha) was obtained from variety Melkasa 6Q. In line with this, location by varieties interactions resulted in significant differences in biomass yield. The most excellent biomass yield $(17188 \mathrm{~kg} / \mathrm{ha})$ was recorded at Kindo Koyisha for variety BH547, followed by variety $\mathrm{BH} 546$ at the exact location with a mean biomass yield of $15938 \mathrm{~kg} / \mathrm{ha}$. The lowest biomass yield $(6979 \mathrm{~kg} / \mathrm{ha})$ was seen for variety Melkasa 6Q at Kindo Koyisha.

Grain yield has significantly differed in response to the location where higher grain yield was obtained from Kindo Koyisha than Humbo (Table 3). Similarly, maize varieties exhibited significant differences in grain yield. The highest grain yield (5208 kg/ha) was recorded at Kindo Koyisha for variety BH546, followed by MH140 with a mean grain yield of $5000 \mathrm{~kg} / \mathrm{ha}$ at the exact location. The lowest grain yield $(2396 \mathrm{~kg} / \mathrm{ha})$ was achieved from Local red at Humbo. In general, maize varieties tested for moisture responded differently to respective environments. At Kindo Koyisha, varieties BH546, MH140, and BH547 showed good performance in a such moisture-stress-prone environments. On the other hand, MH140 and MH130 relatively exhibited superiority over others at Humbo.

Table 4: Biomass, grain yield and harvest index as affected by location and varieties

\begin{tabular}{|c|c|c|c|c|}
\hline Location & Variety & $\begin{array}{l}\text { Biomass } \\
\text { (kg/ha) }\end{array}$ & $\begin{array}{l}\text { Grain } \\
\text { yield (kg/ } \\
\text { ha) }\end{array}$ & HI \\
\hline \multirow{11}{*}{$\begin{array}{l}\text { Kindo } \\
\text { Koyisha }\end{array}$} & BH546 & 15938ab & $5208 a$ & 0.28 \\
\hline & BH547 & 17188a & $4479 \mathrm{ab}$ & 0.26 \\
\hline & Gibe II & 10729b-e & $3438 a-c$ & 0.30 \\
\hline & MH130 & 10417b-e & 3958a-c & 0.35 \\
\hline & Melkasa IV & 8542de & $2917 b c$ & 0.33 \\
\hline & MH140 & 14896a-c & $5000 a$ & 0.32 \\
\hline & Melkasa II & 8646de & $2604 c$ & 0.27 \\
\hline & Melkasa 6Q & $6979 \mathrm{e}$ & $2708 b c$ & 0.38 \\
\hline & Local red & $9583 c-e$ & $2708 b c$ & 0.18 \\
\hline & Local mixed & 10729b-e & $3021 b c$ & 0.24 \\
\hline & Local white & 10104b-e & $2917 b c$ & 0.14 \\
\hline \multirow{12}{*}{ Humbo } & BH546 & 13542a-d & $2917 b c$ & 0.28 \\
\hline & BH547 & 12188a-e & $2500 \mathrm{c}$ & 0.29 \\
\hline & Gibe II & 9375c-e & $2604 b c$ & 0.33 \\
\hline & MH130 & 10104b-e & $3021 b c$ & 0.30 \\
\hline & Melkasa IV & 9375c-e & $2917 b c$ & 0.36 \\
\hline & MH140 & $9375 c-e$ & $3021 b c$ & 0.40 \\
\hline & Melkasa II & 10104b-e & $2708 \mathrm{bc}$ & 0.25 \\
\hline & Melkasa 6Q & $7292 \mathrm{e}$ & $2708 \mathrm{bc}$ & 0.37 \\
\hline & Local red & 11458a-e & $2396 c$ & 0.38 \\
\hline & Local mixed & 11458a-e & $2604 c$ & 0.34 \\
\hline & Local white & 7604de & $2396 c$ & 0.27 \\
\hline & LSD & 5943 & 1860 & NS \\
\hline
\end{tabular}




\begin{tabular}{lllll}
\hline \multirow{7}{*}{ BH546 } & $14792 \mathrm{a}$ & $4063 \mathrm{a}$ & 0.28 \\
& BH547 & $14688 \mathrm{ab}$ & $3438 \mathrm{a}-\mathrm{c}$ & 0.27 \\
& Gibe II & $10104 \mathrm{~cd}$ & $3021 \mathrm{a}-\mathrm{c}$ & 0.32 \\
Variety & MH130 & $10208 \mathrm{~cd}$ & $2500 \mathrm{c}$ & 0.33 \\
mean & Melkasa IV & 8958cd & $2917 \mathrm{a}-\mathrm{c}$ & 0.35 \\
& MH140 & $12188 \mathrm{a}-\mathrm{c}$ & $3958 \mathrm{ab}$ & 0.36 \\
& Melkasa II & $9375 \mathrm{~cd}$ & $2604 \mathrm{c}$ & 0.27 \\
& Melkasa 6Q & $7083 \mathrm{~d}$ & $2706 \mathrm{bc}$ & 0.38 \\
& Local red & $10521 \mathrm{~b}-\mathrm{d}$ & $2396 \mathrm{c}$ & 0.28 \\
& Local mixed & $11146 \mathrm{a}-\mathrm{d}$ & $2813 \mathrm{a}-\mathrm{c}$ & 0.29 \\
& Local white & $8854 \mathrm{~cd}$ & $2604 \mathrm{c}$ & 0.20 \\
& LSD & 4202 & 1316 & $\mathrm{NS}$ \\
\hline \multirow{5}{*}{ Location } & Kindo & 11250 & $3438 \mathrm{a}$ & 0.28 \\
& Koyisha & & & \\
& Humbo & 10208 & $2708 \mathrm{~b}$ & 0.33 \\
& LSD & NS & 673 & NS \\
& CV $(\%)$ & 13.6 & 1.3 .2 & 32.4 \\
\hline
\end{tabular}

Means followed by the same letters within a column are not significantly different at 5\% probability level, NS = not significant.

Maize varieties exhibited differently for agronomic traits measured in response to the location regarding their genetic variability (Table 1, 2, 3, and 4). Generally, almost all maize varieties showed superior performance at Kindo Koyisha compared to Humbo for agronomic traits. The grain yield differences recorded were $730 \mathrm{~kg} / \mathrm{ha}$ between Kindo Koyisha and Humbo. Thus, relatively the performances of varieties were poor at Humbo, which probably suggests that Kindo Koyisha was a relatively better environment with plant growth conditions. Moreover, this illustrated that subjecting plants to favourable growing conditions increased the ability of varieties to capture resources, which was reflected as evident in their increased agronomic performance. The significant effects of environments indicated that the genotypes performed differently across locations. Thus, the mean yield of genotypes differed from location to location.

Similarly, maize varieties, averaged over locations, showed significant differences in plant height, ear height, rows per cob, seeds per row, seeds per cob, ear length, and ear diameter (Table 1, 23). Relatively higher plant height $(\geq 200 \mathrm{~cm})$ was recorded for varieties BH546, BH547, and MH140, whereas ear heights $(\geq 100 \mathrm{~cm})$ were recorded for varieties BH547, Local mixed, and Local white. Variety BH546 gave the most extended cob length, while BH547 produced the highest cob diameter. Variety BH547 gave the highest number of rows per cob, while variety $\mathrm{BH} 547$ produced the most significant number of seeds per row and seeds per cob. Maize varieties averaged over locations tended to express a wide range of their genetic variability for grain yield. Grain yield variations ranged from 2396 to $4063 \mathrm{~kg} / \mathrm{ha}$. Variety BH 546 out yielded which MH140 followed. Local red was the least concerning grain yield performance. The significant difference among the genotypes showed variations in their response (yield potential) to different locations.

Location by variety interactions resulted in significant differences on-ear height, cob length, seeds per row, biomass, and grain yield (Table 1, 2 \& 3). For parameters as mentioned above, varieties had relatively superiority at Kindo Koyisha as compared to Humbo. In general, the performance of varieties was poor at Humbo, with the grain yield variability ranged from 2396 to $3021 \mathrm{~kg} / \mathrm{ha}$. At Humbo varieties, MH140, MH130, BH546, and Melkasa IV gave relatively higher grain yield with $\mathrm{HI}$ (Physiological efficiency and ability to convert total dry matter into economic yield) values $0.30,0.40,0.28$, and 0.36 , respectively. This variability might be attributed to varietal differences in maize genotypes in response to the prevailing environmental conditions. Hence, the Humbo location could be considered a stressful environment with profound limitations in the potential performance of maize varieties. At Kindo Koyisha, maize varieties expressed relatively better performance concerning grain yield. Grain yield variability ranged from 2604 to $5208 \mathrm{~kg} / \mathrm{ha}$ from lowest to the highest. At this location, varieties with superior performance with sounding grain yield were BH546, MH140, BH547, and MH130. This probably indicates that genotypes describe the complete set of genes inherited by an individual important for expressing a trait under consideration in a particular environment.

In general, maize varieties at Kindo Koyisha performed best to their potential as compared to Humbo. Maize varieties BH546, MH130, and MH140 showed relative stability across the location with superiority of grain yield. The research results indicated that genotype by environment $(G \times E)$ interactions is a differential genotypic expression across environments which affects the genotypes rankings within each environment and hence relevant for identifying mega environments and targeting genotypes. Moreover, $G \times E^{\prime}$ s 
significance indicates fluctuation of genotypes performance across environments or testing sites with inconsistent performance. Similar results were recorded by Akcura et al. (2005), Acura and Kaya (2008), Asfaw (2008), Dagne (2008), Solomon et al. (2008), Abdurhaman (2009), and Muluken (2009). The relationship between selected agronomic traits with the grain is depicted in Table 5. The correlation coefficient (r) values of selected agronomic traits with grain yield ranged from -0.05 to 0.82 . Plant and ear height were positively significantly $(\mathrm{P} \leq$ 0.05 ) correlated, suggesting that the traits are closely associated with grain yield.

Table 5: Correlation of growth and yield components with grain yield

\begin{tabular}{ll}
\hline Parameter & Grain yield \\
\hline Plant height & $0.82^{*}$ \\
Ear height & $0.68^{*}$ \\
Number of rows per cob & $-0.05^{\mathrm{NS}}$ \\
Number of seeds per row & $0.72^{*}$ \\
Number of seeds per cob & $0.60^{*}$ \\
Ear length & $0.72^{*}$ \\
Ear diameter & $0.56^{*}$ \\
Biomass & $0.78^{*}$ \\
Thousand seed weight & $0.77^{*}$ \\
\hline
\end{tabular}

Similarly, the number of seeds per row, seeds per cob, ear length, ear diameter, biomass, and TSW were positively associated with yield. In contrast, the number of rows per cob with grain yield correlation was not significant. The correlation of almost all agronomic traits with grain yield was relatively strong, indicating that their contribution towards grain yield was considerable.

\section{CONCLUSION}

Maize varieties reacted differently for agronomic traits measured in response to the location regarding their genetic variability. Generally, almost all maize varieties exhibited superior performance at Kindo Koyisha than that of Humbo. Based on this result, varieties BH546, MH140, and MH130 could be used at both locations. Moreover, varieties BH546 and $\mathrm{MH} 140$ at Kindo Koyisha, whereas varieties $\mathrm{MH}$ 140, MH 130, and Melkasa IV at Humbo showed relatively better adaptation to their respective locations

\section{REFERENCES}

Abdurhaman, B. 2009. Genotype by environment interaction and yield stability of maize genotypes evaluated in Ethiopia. M.Sc thesis Department of Plant Sciences/Plant Breeding. University of the Free State Bloemfontein, South Africa.

Acura, M.Y. and Kaya. 2005. Nonparametric stability methods for interpreting genotype by environment interaction of bread wheat genotypes (Triticum aestivum L.). Genet. Mol. Biol., 31(4): 906- 913.

Acura, M.Y., Kaya, Taner, S. and Ayranci, R. 2006. Parametric stability analysis for grain yield of drum wheat. Plant Soil Environ., 52(6): 254-26.

Akcura, M.Y., Yaya, Taner, S. 2005. Genotype-environment interaction and phenotypic stability analysis for grain yield of durum wheat in the Central Anatolian region. Turkey J. Agric., 29: 369-375.

Asfaw, A. 2008. Assessment of yield stability in sorghum using univariant and ultivariant statistical approaches. Hereditas, 145: 28-37.

CSA (Central Statistical Agency), 2010. Federal democratic republic of Ethiopia Crop Production Forecast Sample Survey, Statistical Bulletin. Addis Ababa.

Dagne, W. 2008. Genotypic variability and combining ability of quality protein maize inbred lines under stress and optimal conditions. Philosophiae Doctor Department of Plant Sciences. University of the Free State, South Africa.

FAO (Food and Agricultural Oorganization), 2003. Yearbook of maize production 177: 265.

Maredia, M., Byerlee, D. and Pee, P. 2000. Impacts of food crop improvement research: Evidence from Sub-Saharan Africa. Food Policy, 25: 531-559.

Mosisa, W., Hadji, T., Mandefro, N. and Abera, D. 2002. Maize production trends and research in Ethiopia. In: N. Manderfo, D. Tanner and S. Afriyie (eds.). Proceeding of the second National Maize Workshop of Ethiopia. 12-16 November 2001, Addis Ababa, Ethiopia.

Muluken, B. 2009. Analysis and correlation of stability parameters in malting barley. Uganda. Afr. J. Crop Sci., 17(3): 145-153.

Palwal, R.L. 2000. Introduction to maize and its importance: Tropical maize: Improvement and production. Pp 1-3. In: Plant production and protection series No. 28.

Pingali, P.L. and Pandey, S. 2001. Meeting world maize needs: Technological opportunities and priorities for public sector. Pp 1-20. In: Pingali, P.L. (ed.). CIMMYT 1999-2000. World Maize Facts and Trends. CIMMYT, Mexico. 
Doha et al.

Parewa, H.P., Rakshit, A., Rao, A.M., Sarkar, N.C. and Raha, P. 2010. Evaluation of maize cultivars for phosphorus use efficiency in an Inceptisol. Int. J. Agric. Environ. Biotechnol, 3(2):195-198.

SAS. 2003. Statistical Analysis System. SAS Release 9.1 for windows, SAS Institute Inc.Cary, NC, USA.
Solomon Admassu, Mandefro Nigussie and Habtamu Zeleke, 2008. Genotype-by environment Ineraction and Stability Analysis for Grain yield of Maize (Zea mays L.) in Ethiopia. Asian J. Plant Sci., 7(2): 163-169.

Vasal, S.K. 2000. The quality maize story. Food Nutr. Bulletin, 12: 445. 